\title{
Indonesian Dairy Industry Perspective within the ASEAN Economic Community
}

\author{
Atien Priyanti and TD Soedjana \\ Indonesian Center for Animal Research and Development (ICARD) \\ Jalan Raya Pajajaran Kav. E-59, Bogor 16128 \\ atienpriyanti@yahoo.com
}

(Accepted 27 January 2015 - Revised 6 July 2015 - Approved 23 October 2015)

\begin{abstract}
Many of Indonesian main manufacturing industries based on agriculture should be more responsive to the challenging domestic and global strategic environment, including the newly emerging ASEAN economic community (AEC) which will be effectively implemented by the end of 2015. Dairy industry in Indonesia is a very potential business to play significant role in the ASEAN market based on the existing dairy population, feed resources and the number of dairy farmers. Recently, small and medium enterprise (SME) model in Java has been developed for processing milk. They provide higher farm gate prices under partnership agreement which created a good benchmark and business model for the future dairy industry to adopt. This new attractive business environment gives higher return to the farmers as opposed to the tradition of paying low farm gate milk prices. As feed represents $80 \%$ of the total production cost, special attention must be given to land availability to increase feed supply in terms of quality and quantity. Consequently, sustainable support from both central and local government is very critical to keep the partnership model between farmers and the SME milk processing. It also opens new opportunity to increase the linkage more closely between producers and milk processing plants.
\end{abstract}

Key words: SME dairy industry, Indonesia, ASEAN economic community

ABSTRAK

Perspektif Industri Susu di Indonesia dalam Masyarakat Ekonomi ASEAN

Industri-industri manufaktur utama Indonesia berbasis pertanian harus lebih responsif terhadap tantangan strategis baik domestik maupun global, termasuk masyarakat ekonomi ASEAN (MEA) yang akan efektif dilaksanakan pada akhir tahun 2015. Industri susu di Indonesia adalah bisnis yang sangat potensial untuk berperan signifikan di pasar ASEAN berdasarkan populasi sapi perah, sumber pakan dan jumlah peternak yang ada. Baru-baru ini, model usaha mikro, kecil dan menengah (UMKM) untuk pengolahan susu telah berkembang di Jawa. Usaha ini memberikan harga di tingkat petani lebih tinggi berdasarkan perjanjian kemitraan yang menciptakan tolok ukur yang baik dan dapat diadopsi sebagai model bisnis industri susu di masa depan. Lingkungan bisnis baru yang menarik ini memberikan pendapatan peternak yang lebih tinggi dibandingkan model tradisional yang menyebabkan peternak menerima harga susu lebih rendah. Kenyataan bahwa biaya pakan mencapai $80 \%$ dari total biaya produksi, maka perlu perhatian khusus pada ketersediaan lahan untuk meningkatkan pasokan pakan dari segi kualitas dan kuantitas. Sehubungan dengan itu, dukungan pemerintah pusat dan daerah yang berkelanjutan sangat penting untuk menjaga kesinambungan kemitraan antara peternak dan UMKM pengolahan susu. Hal ini membuka peluang baru untuk meningkatkan hubungan yang lebih erat antara produsen dan pabrik pengolahan susu.

Kata kunci: Industri susu UMKM, Indonesia, masyarakat ekonomi ASEAN

\section{INTRODUCTION}

Indonesia strong annual economic growth of $6 \%$ per year for the last three years 2010-2012, has been absolutely driven by the manufacturing and services sectors with some structural changes in production. However, agriculture sector remains the largest sector, in terms of employment since this sector has more than $50 \%$ of the total national workforce, while consistently plays significant role in export earning, that is from around $12 \%$ of merchandise exports or about $30 \%$ of non-oil and non-gas exports (BPS 2014). Since the agricultural sector is mainly based on domestic resources, therefore it is a slightly affected by global economic fluctuations. Meanwhile, as a natural resource based sector, Indonesian agriculture somewhat is insulated from domestic macroeconomic shocks such as monetary, exchange rate and fiscal fluctuations. Many of Indonesian main manufacturing industries are agricultural based and if it is to be a basis for the recovery and growth of the economy, Indonesian agriculture must, therefore, become more responsive to 
the challenging domestic and global strategic environment, including the newly emerging ASEAN economic community (AEC) which will be effectively implemented by the end of 2015 .

In Indonesia, milk and milk products have long been considered as strategic commodities to meet nutritional food requirement for human being, therefore, it should be reliable for value added taxes free to keep it growing and becoming more competitive, especially in the marketing and processing industry. Dairy products will continue to provide opportunities for the milk processing industry to expand its capacity since more than 45 million people of the consuming class, that is around $53 \%$ of the population in cities producing $74 \%$ of gross domestic product (GDP), 55 million skilled workers in the Indonesian economy and $\$ 0.5$ trillion market opportunity in consumer services, agriculture and fisheries, resources and education (Oberman et al. 2012). Dairy sector in Indonesia, with its prevalence capacity to produce domestic fresh milk year round, coupled with growing middle and upper income groups as potential consumers, has been experiencing substantial high raw material import volume (78\%) for the milk processing industry. Along with Indonesia stable political climate, increasing per capita milk consumption and a growing awareness toward general health status of the society as a direct benefit from dairy product, the Indonesian milk processing industry will continue to grow and provide opportunities for Indonesian economy. This perspective is very visible from the fact that the dairy manufacturers are expanding their capacity, to stimulate domestic dairy industry which is currently growing at an annual rate of 8\% (Darmawan 2013).

Although several major dairy farms are expanding their herd number, the overall growth of domestic fresh milk production remain limited to some degree and tends to put in a relatively stagnant position of domestic milk production, which in turns reduces its contribution to meet the demand from growing dairy industry in the near future. This is a true challenge to the sector, especially when the industry is building its capacity towards implementable AEC in 2015. Indonesian dairy milk industry has been supplied fresh milk from dairy farmers, where majority involved as member of a local dairy cooperative union (KUD). The KUD then collects and sends the milk to milk processors. Tawaf et al. (2009) stated that only $8 \%$ of milk from individual dairy farmers goes directly to final consumers as fresh liquid milk or yoghurt drinks. Milk processors may manufacture this milk into liquid milk, condensed milk, powdered, ice cream and yoghurt. This will follow by packaging and labeling of milk product and picked up by distributors before selling into supermarkets or outlets where final consumers need to buy it. This paper reviews some of potential competitiveness of Indonesian dairy industry to take advantages of higher production value within the country as well as in the region within the frame of AEC in 2015.

\section{IMPLICATIONS OF AEC ON INDONESIA DAIRY INDUSTRY}

During the $9^{\text {th }}$ Summit of the Association of Southeast Asian Nations (ASEAN) in Bali, Indonesia in 2003, the ASEAN Heads of Government passed the Declaration known as the Bali Concord II which pronounced the establishment of an ASEAN Community by the year 2020. The declaration determined to achieve higher levels of economic dynamism, sustained prosperity, inclusive growth and integrated development of ASEAN as well as in order to promote greater political, security and economic cooperation in the region. One of the frameworks in this accord was the ASEAN economic community (AEC) which envisions economic integration in the region through the concept of free flow of goods, services, investments, capital and skilled labor (AEC 2008). In 2007, during the $12^{\text {th }}$ ASEAN Summit in Cebu, Philippines, the ASEAN Leaders agreed to accelerate the establishment of the ASEAN Community by 2015 , as envisioned in the ASEAN Vision 2020 and the ASEAN Concord II and signed the Cebu Declaration on the Acceleration of the Establishment of an ASEAN Community. In the following Summit in Singapore in November 2007, the Leaders signed and adopted the AEC blueprint which serves as the detailed master plan in establishing the AEC by 2015. The AEC blueprint stated that it "will transform ASEAN into a single market and production base, a highly competitive economic region, a region of equitable economic development, and a region fully integrated into the global economy" (AEC 2008).

The AEC goal of regional economic integration rests on four pillars, namely (1) Single market and production base; (2) Competitive economic region; (3) Equitable economic development; and (4) Full integration into the global economy. Under each pillar are core elements which require specific actions and strategic approaches to realize the intended outcomes (Table 1). These characteristic are inter-related and mutually reinforcing, in addition incorporating the required elements of each characteristics shall ensure the consistency and coherence of these elements as well as their implementation and proper coordination among relevant stakeholders.

The food, agriculture and forestry sectors are important component under the single market and production base pillar of the AEC. Specifically, the 
AEC intents to implement further enhancement of intra and extra-ASEAN agricultural trade through the reduction and removal of tariffs via the CEPT-AFTA, removal of non-tariff barriers and the adoption and harmonization of quality management systems for food safety. This will also include cooperation and technology transfer with international organizations and private sector as well as market access through ASEAN agricultural cooperatives. These aspects would be very much relevant with the business of dairy sector in Indonesia. Under ASEAN trade in goods and agreement (ATIGA), the ASEAN six countries, including Indonesia, currently impose zero tariffs on all dairy products based on ASEAN harmonized tariff nomenclature (AHTN) in 2012. Cambodia, Lao PDR,
Myanmar and Vietnam impose non-zero tariffs in some dairy products in the AEC period (Table 2). The most favorable nation (MFN) tariff rates for agricultural products remain low in most of the ASEAN countries. The reduction and or elimination tariffs would increase the value of intra and extra-ASEAN trade in the agricultural, including dairy sector.

Given the steady decline in tariffs for dairy products in the region, with around 600 million populations where $42 \%$ lives in Indonesia, important trade aspect would be the most challenging issue for dairy industry in Indonesia. This will also be driven by positive economic indicator in 2014 as was considered fairly good in terms of its GDP annual growth rate measure of $5.1 \%$ along with its moderate inflation rate

Table 1. Pillars and core elements of the ASEAN economic community blueprint

\begin{tabular}{|c|c|}
\hline Core elements & Key strategic areas of action \\
\hline \multicolumn{2}{|c|}{ Pillar 1: Single market and production base } \\
\hline \multirow[t]{7}{*}{ A1. Free flow of goods } & Removal/reduction of tariffs \\
\hline & Removal of non-tariff barriers \\
\hline & Rules of origin \\
\hline & Trade facilitation \\
\hline & Customs integration \\
\hline & ASEAN single windows \\
\hline & Standards and technical barriers to trade \\
\hline \multirow[t]{4}{*}{ A2. Free flow of services } & $\begin{array}{l}\text { Remove substantially all restrictions on trade and services under ASEAN framework } \\
\text { agreement on services }\end{array}$ \\
\hline & Scheduled commitments for national treatment limitations \\
\hline & Complete mutual recognition arrangements (MRAs) \\
\hline & Liberalization measures of the financial services sector \\
\hline \multirow[t]{2}{*}{ A3. Free flow of investment } & $\begin{array}{l}\text { ASEAN investment cooperation is being implemented through ASEAN investment } \\
\text { agreement (AIA) }\end{array}$ \\
\hline & $\begin{array}{l}\text { Provide enhance investment protection as well as facilitation and cooperation likewise } \\
\text { promotion and awareness }\end{array}$ \\
\hline \multirow[t]{2}{*}{ A4. Free flow of capital } & Strengthening ASEAN capital market development and integration \\
\hline & Allowing greater capital mobility \\
\hline A5. Free flow of skilled labour & $\begin{array}{l}\text { Manage mobility or facilitate entry for the movement of natural persons engaged in trade } \\
\text { in goods, services and investments }\end{array}$ \\
\hline \multirow[t]{2}{*}{$\begin{array}{l}\text { A6. Priority integration } \\
\left.\text { sectors }{ }^{*}\right)\end{array}$} & $\begin{array}{l}\text { Twelve priority integration sectors develop a roadmap which combines specific initiatives } \\
\text { and the broad one }\end{array}$ \\
\hline & $\begin{array}{l}\text { Allows the region to focus its limited resources and deep integration in these critical areas } \\
\text { while provides ASEAN members to jointly develop a stronger sense to economic } \\
\text { integration prior to a broader roll-out }\end{array}$ \\
\hline \multirow[t]{4}{*}{$\begin{array}{l}\text { A7. Food, agriculture and } \\
\left.\text { forestry }^{*}\right)\end{array}$} & $\begin{array}{l}\text { Monitor implementation of common effective preferential tariffs for ASEAN free trade } \\
\text { area (CEPT-AFTA) within agriculture and forestry products }\end{array}$ \\
\hline & Harmonization and application of quality standards for food safety \\
\hline & Cooperation and technology transfer with international organisations and private sector \\
\hline & Market access through ASEAN agricultural cooperatives \\
\hline
\end{tabular}

\footnotetext{
${ }^{*}$ including the two important components on the first pillar
} 
Table 1. Pillars and core elements of the ASEAN economic community blueprint (continued)

\begin{tabular}{|c|c|}
\hline Core elements & Key strategic areas of action \\
\hline \multicolumn{2}{|c|}{ Pillar 2: Highly competitive economic region } \\
\hline \multirow[t]{2}{*}{ B1. Competition policy } & Establish a network of authorities responsible and develop regional guideline \\
\hline & Encourage capacity building and adoption of best practices \\
\hline B2. Consumer protection & Establish ASEAN coordinating committee on consumer protection (ACCCP) \\
\hline B3. Intellectual property rights & Fully implemented Intellectual Property Rights action plan \\
\hline \multirow[t]{3}{*}{ B4. Infrastructure development } & Transport cooperation \\
\hline & $\begin{array}{l}\text { ASEAN framework agreement on multi-moda transport and transport facilitation: Land, } \\
\text { maritime and air transport }\end{array}$ \\
\hline & Develop information infrastructure and energy cooperation \\
\hline B5. Taxation & Build bilateral agreements on avoidance of double taxation \\
\hline B6. E-commerce & Develop E-commerce best practices of regulations \\
\hline \multicolumn{2}{|c|}{ Pillar 3: Equitable economic development } \\
\hline C1. SME development & Timely implementation of ASEAN policy blueprint for SME development \\
\hline $\begin{array}{l}\text { C2. Initiatives for ASEAN } \\
\text { integration (IAI) }\end{array}$ & $\begin{array}{l}\text { Give the direction and sharpen the focus of collective efforts to narrow the development } \\
\text { gap not only between ASEAN but between ASEAN and other countries as well }\end{array}$ \\
\hline \multicolumn{2}{|c|}{ Pillar 4: Full integration into the global economy } \\
\hline $\begin{array}{l}\text { D1. Coherent approach } \\
\text { towards external } \\
\text { economic relations }\end{array}$ & $\begin{array}{l}\text { Establish a system for enhanced coordination for free trade and comprehensive economic } \\
\text { partnership }\end{array}$ \\
\hline \multirow[t]{2}{*}{$\begin{array}{l}\text { D2. Enhanced participation in } \\
\text { global supply networks }\end{array}$} & $\begin{array}{l}\text { Continuing the adoption of international best practices and standards in production and } \\
\text { distribution }\end{array}$ \\
\hline & $\begin{array}{l}\text { Developing a comprehensive package of technical assistance to upgrade capability and } \\
\text { productivity }\end{array}$ \\
\hline
\end{tabular}

Source: AEC (2008)

Table 2. Tariff implementation of dairy products in ASEAN countries

\begin{tabular}{lccccc}
\hline \hline \multirow{2}{*}{ Countries } & Average MFN applied (\%) $\left.)^{*}\right)$ & \multicolumn{4}{c}{ ATIGA tariff by year $\left.(\%)^{* *}\right)$} \\
\cline { 3 - 6 } Brunei Darussalam & n.a & n.a & n.a & n.a & 013 \\
Cambodia & 15.2 & 5 & 5 & 5 & $0-5$ \\
Indonesia & 7.5 & 0 & 0 & 0 & 0 \\
Lao-PDR & na & 5 & 5 & 5 & 5 \\
Malaysia & 8.9 & 0 & 0 & 0 & 0 \\
Myanmar & 8.6 & $3-5$ & $3-5$ & $3-5$ & $0-5$ \\
Philippines & 9.9 & $3-7$ & 0 & 0 & 0 \\
Singapore & 1.4 & 0 & 0 & 0 & 0 \\
Thailand & 29.9 & 0 & 0 & 0 & 0 \\
Vietnam & 16.2 & 5 & 5 & 5 & $0-5$ \\
\hline
\end{tabular}

n.a: Not available; MFN: Most Favorable Nation; ATIGA: ASEAN Trade in Goods and Agreement

Source: ${ }^{*}$ WTO (2014); ${ }^{* *}$ ASEAN Tariff Schedules 2013

of $6.23 \%$ (BPS 2014). Domestic consumption is the major driver of Indonesia economic activity, where consumption accounted for $61 \%$ of national GDP and is expected to reach $65 \%$ in the next 20 years. This would be a tremendous potential for Indonesia consumer market as the economy continues to grow and the consumers become wealthier with obvious tend to consume preferably non-staple food, such as dairy products. Annual consumer spending is projected to increase by $7.7 \%$, while current trends indicate that 
Indonesia is likely to become the seventh-largest economy in the world by 2030 compared with current position as the sixteenth (Oberman et al. 2012). It is very obvious that Indonesian economy is transforming rapidly with growing young population while quickly urbanizing, hence empowering the growth in income. This growth of consuming class would indicate prospective future to worldwide business and investors for its considerable new opportunities.

The promoting of emerging creative small and medium enterprises will be fully supported by the new government, which is actively pursuing smallholder farmers to gain better life. This objective is indeed in line with the priority initiative as indicated in the AEC Blueprint particularly to enhance its pillar number $\mathrm{C}$, i.e. the strategic importance of small and medium sized enterprises for equitable growth. The development of facilitating access to finance, information, market and technology are very important since most of the dairy industry is characterized by smallholders with limited size of cow ownership and marketing of their fresh milks is only one option through cooperatives. Combined with Indonesia stable political climate, stronger per capita milk consumption, and greater awareness of the health benefits from dairy products, dairy industry will continue to provide opportunities for the economy to grow. Indonesian economy's growth could also benefit from current powerful trends to meet the challenges ahead through improvement of transforming consumer services, boost productivity in agriculture and fishery, creating a smart economy resource as well as skill building investment.

In addition to those factors above, Indonesia has improved its position by four up stepping in the world economic forum's global competitiveness index in 2014-2015, which places Indonesia currently at $34^{\text {th }}$ place out of 144 countries, compared to previous position on $38^{\text {th }}$ place $(2013-2014)$ (WEF 2014). The global competitive index measures the institution, policies, as well as factors that set sustainable current and medium period levels of economic prosperity among 144 countries around the world, where Indonesia improved steadily from rank $50^{\text {th }}$ since the year 2012-2013. The successful increase in rank is due mainly to improvements in macroeconomic environment experiences that significantly increase recently. This increase reflects continuous improvements in Indonesian national economic performance as a positive indicator to enhance competitiveness within the ASEAN region. Nevertheless, it also shows that Indonesia still lags behind from some regional countries such as Malaysia and Thailand with their current ranks of $20^{\text {th }}$ and $31^{\text {th }}$ place, respectively. A serious effort and commitment need to be implemented to sort out some of critical points such as the needs to develop infrastructure continually, bureaucratic reform for efficient services and corruption eradication. Table 3 shows a more detail of the global competitiveness index ranking in 20142015 and in 2013-2014 of the ASEAN countries.

\section{POTENTIAL GROWTH OF INDONESIA DAIRY PRODUCTION}

It has been well known that the role of the small holder producers in the dairy industry is very significant. They produced about $90 \%$ of the total fresh milk production in this country. Milk production increased rapidly by $18.7 \%$ during the period of 2009 2013 , or $4.7 \%$ annually (DGLAHS 2013) and that daily fresh domestic milk production has reached 1.02 million ton. The most recent census on cattle and buffalo population indicated that dairy cattle population was close to 622 thousand heads and $59.95 \%$ of it were cows (DGLAHS 2013). East Java is considered the

Table 3. The global competitiveness index (GCI) 2014-2015 and 2013-2014 rankings of ASEAN countries

\begin{tabular}{lccc}
\hline \hline Countries & GCI 2014-2015 rank (out of 144) & Score (1-7) & GCI 2013-2014 rank (out of 148) \\
\hline Malaysia & 20 & 5.16 & 24 \\
Thailand & 31 & 4.66 & 37 \\
Indonesia & 34 & 4.57 & 38 \\
Philippines & 52 & 4.40 & 59 \\
Vietnam & 68 & 4.23 & 70 \\
Lao-PDR & 93 & 3.91 & 81 \\
Cambodia & 95 & 3.89 & 88 \\
Myanmar & 134 & 3.24 & 139 \\
Brunei Darussalam & n.a & n.a & n.a \\
Singapore & n.a & n.a & n.a \\
\hline
\end{tabular}

n.a: Not available

Source: WEF (2014) 
most important milk production area of Indonesia which shares $50 \%$ population and $56 \%$ share of the total milk production of this country (Table 4). Seven major milk producing districts in the country include Malang and Pasuruan in East Java, Semarang and Boyolali in Central Java, Lembang and Bandung in West Java along with Sleman in Yogyakarta. The average yield is between 10-12 liters/cow/day. This dairy farming has been involving 125 thousand farmers which dispersed into 1,500 farmer groups within 95 primary cooperatives. It is predicted that there is a potential calf's birth of 140 thousand heads or approximately require 70 thousand heifers as replacement stocks per year. Table 4 explains a more detail dairy population and its production from the main provinces that serve as the milk production center areas in Indonesia.

In addition to the current production areas on Java, the government has supported the initiative for developing dairy industry in new areas out of the Java Island. The new areas include Sumatra (North Sumatra, Jambi, West Sumatra and South Sumatra), South Kalimantan and South Sulawesi. The support on this initiative was mainly based on the fact that there is considerable and potential feed resources in this region to solve basic problem that feed requirements would be no longer persistence due to land shortages such as in the island of Java. In addition, more agricultural and or agro-industry by products are available abundantly as extensive estate plantations are mostly located in these areas. Since the availability and efficient use of the feed resources are the primary drivers of performance to maximize dairy productivity, therefore, the areas will have comparative advantage in terms of geographical proximity as they are located close to the neighboring countries such as Malaysia, Singapore and Thailand. This is also relevant to previous study by Devendra \& Leng (2011) that reported feed security is fundamental to the management, extent of use, conservation and intensification for livestock productivity enhancement.

The national per capita milk consumption currently stands at 11.7 1/year, which is obviously lower compared to that in some ASEAN countries such as Thailand (30.1 1), Malaysia (30.0 1) and Vietnam
(15.0 1) (Darmawan 2013). It is expected that national milk consumption would increase by $8 \%$ this year compared to that of 2012. This expectation of increase would be triggered by increased in human population (1.45\% per year), consumer's income, and improved nutrition awareness. In recent years, consumers prefer to drink more liquid ready fresh milk and UHT milk which continue to dominate the market.

Current local milk production has contributed only $22 \%$ of the total milk supply, which justify that Indonesia has to import the rest of $78 \%$ to fulfill the demand equals to 178.8 thousand ton of milk and milk products or equivalent to USD 603 million in 2012 (DGLAHS 2013). The tremendous potential milk production and market for the country along with its initiative to extend the production areas would also stimulate the dairy industry to take advantage of export markets within the perspective of new markets of the ASEAN region.

Milk quality as one of important aspects in the effort to improve the industry's competitiveness in the region is among high priorities for the government to facilitate the industry to rise standards of its products. Quality of fresh milk is generally measured by the bacteria content in terms of total plate count (TPC), which range from 500 thousand to 1 million. Price incentives have been used to encourage better farm management practices and higher quality milk, however some are still perform far below the minimum standard of national quality standard (SNI), i.e. a maximum of 1 million for TPC, a minimum of $11 \%$ for total solids, and milk content (protein of minimum $2.7 \%$; fat minimum of $3 \%$ and solid non fat at minimum of $8 \%$ ). Dairy cooperative union (KUD) collects and measures bacteria content of the fresh milk from farmers to determine the quality and price paid to farmers. Despite improving technical aspect to increase milk quality under farmer's condition, it is also important to seek other approaches in cope with the role of the KUD. Devitt et al. (2013) stated that application of collective action in the organization of milk cooperatives need to be implemented, this include extension program involving advisors and dairy farmers along with building industry's capacity.

Table 4. Dairy cow's population and milk production by main provinces, 2013

\begin{tabular}{lcccc}
\hline \hline Province & Dairy cow population (head) & Dairy cow population (\%) & Milk production (ton) & Milk production (\%) \\
\hline East Java & 309,775 & 49.8 & 570,082 & 56.0 \\
Central Java & 152,220 & 24.5 & 106,224 & 10.4 \\
Yogyakarta & 3,613 & 0.6 & 3,260 & 0.3 \\
West Java & 147,958 & 23.8 & 326,115 & 32.0 \\
Others & 8,414 & 1.4 & 12,249 & 1.2 \\
\hline Total & 621,980 & 100.0 & $1,017,930$ & 100.0 \\
\hline
\end{tabular}

Source: DGLAHS (2013) 
Facilitated communication process and creating incentives are important to encourage agreement among different stakeholders.

\section{TRADE OF FRESH MILK PRODUCT IN INDONESIA}

Over $90 \%$ of daily fresh milk production from the smallholder farmers is collected by the KUD and supplied to the milk processing industry as major buyers. The industries produce milk powder, sweetened condensed milk, pasteurized milk, cheese, butter and others. Three types of consumer products dominate the market are powdered milk, sweetened condensed milk (SCM) and ultra high temperature (UHT) milk with their market share of 39,35 and $26 \%$, respectively (GAIN 2013). Consumers' preference for fresh products is expected to continue boosting fluid milk growth that has currently expanded to $17 \%$ annually over the past seven years. There are nine major milk processing companies in this country during 2011 in which Nestle is the biggest share to total market (47\%). The Ministry for Industry reported that in 2011 milk powder was the product which dominated national consumption (43.3\%), followed by sweetened condensed milk (20.4\%). The use of milk as raw material for biscuits, ice cream, candy, chocolate and others are also high $(27.5 \%)$. On the other hand, liquid milk consumption is considered low (8.5\%) which consist of UHT (4.6\%), sterilized milk $(2.7 \%)$ and pasteurized milk $(1.2 \%)$. This figure indicated that there is a huge potential to increase liquid milk production to meet the demand for consumption. To attract more participation in milk consumption, packaging may become another important issue despite it adds the production cost.

Indonesia imports various milk and cream, not concentrated nor sweetened or concentrated whether or not sweetened by various fat content by weight, not exceeding $1 \%$, exceeding $1 \%$ but not exceeding $6 \%$, that experienced slow in 2013 due to tight international supplies. During the period of 2008-2012 value of the milk and milk products imported was around USD 995.469 million shown an increasing of 5.3\% per year (Table 5) (Kemenperin 2013). In the year of 20082009 , it can be shown that all of the milk products had decreased significantly, especially for milk and cream, concentrated whether or not sweetened, in powder, granules or other solid forms, of a fat content, by weight not and exceeding $1.5 \%$. This could be caused by impact of global financial crisis that started in mid 2007 and ended by end of 2008 to make shortages of milk supplied. Besides, depreciation of IDR exchange rate into US dollars may still influence the decreased. During the period of 2010-2012 most of milk products has increased steadily that indicated dairy industry has suffered from the global financial crisis. The main products imported were skim milk and whole milk products, where the main exporters came from European Union, New Zealand, USA and Australia.

The national union of dairy cooperative (GKSI 2013), a secondary cooperative plays the role in coordination primary milk cooperatives. One of GKSI responsibility is to negotiate milk price with major buyers. However, it always the case that low milk prices paid by the major milk processors, while low bargaining power at the GKSI side are obvious implication from the fact that more than $90 \%$ of the milk goes into this industry. Consequently, the ratio of farm gate milk price has decreased persistently from 0.53 to 0.62 during the period of $1999-2008$ (Priyanti \& Saptati 2009) or equivalent to 0.52 in 2013 calculated using current price (Table 6). This figure indicates that the price of fresh raw milk from farmers is less valued compared to that of imported full cream milk powder include $5 \%$ tax and $2.5 \%$ transport cost. The depreciation of rupiah to US dollar as shown by decreasing exchange rate in 2013 has also influenced the ratio of farm gate price to import. Therefore, one of the main crucial issues that need special attention from government point of view is to facilitate and to establish a control mechanism to improve milk price from the buyers. This step may stimulate farmer producers to naturally improve production performance at the attractive farm gate price.

One of the important measures in order to get better farm gate price is income over feed cost (IOFC), which take into consideration the change in the margin over feed cost. This will also allow to describe changes of milk to feed price ratio to estimate profitability when the price changes are largely driven by the price in time series. Wolf (2010) has indicated that IOFC is a better proxy to estimate dairy farm profitability, due to feed price volatility changes in the series of time period without any sign of a decline in milk price volatility. This case is most likely happened in Indonesia, smallholder dairy farm, where feed price increases year by year, while no significant increases on farm gate milk price. IOFC is fairly easy to calculate with readily available price data on feed efficiency and milk production.

\section{COMPETITIVENESS OF SMALL-MEDIUM ENTERPRISE FOR MILK INDUSTRY}

Issues on production efficiency and cost will eventually become the major factors and their consequences for the competitiveness of Indonesia milk industry within the perspective of the AEC 2015 market. In this instance, the small and medium enterprise (SME) will play key important role in national economy. The reasons are: (1) It covers 55.2 
WARTAZOA Vol. 25 No. 4 Th. 2015 Hlm. 159-170

Table 5. Imported milk and milk products based on HS number, 2007-2012

\begin{tabular}{|c|c|c|c|c|c|c|c|c|c|c|}
\hline \multirow[b]{2}{*}{ Products } & \multicolumn{2}{|c|}{2008} & \multicolumn{2}{|c|}{2009} & \multicolumn{2}{|c|}{2010} & \multicolumn{2}{|c|}{2011} & \multicolumn{2}{|c|}{2012} \\
\hline & $\begin{array}{c}\text { Vol. } \\
\text { (000 tonnes) }\end{array}$ & $\begin{array}{c}\text { Value } \\
\text { (000 USD) }\end{array}$ & $\begin{array}{c}\text { Vol. } \\
\text { (000 tonnes) }\end{array}$ & $\begin{array}{c}\text { Value } \\
\text { (000 USD) }\end{array}$ & $\begin{array}{c}\text { Vol. } \\
\text { (000 tonnes) }\end{array}$ & $\begin{array}{c}\text { Value } \\
\text { (000 USD) }\end{array}$ & $\begin{array}{c}\text { Vol. } \\
\text { (000 tonnes) }\end{array}$ & $\begin{array}{c}\text { Value } \\
\text { (000 USD) }\end{array}$ & $\begin{array}{c}\text { Vol. } \\
\text { (000 tonnes) }\end{array}$ & $\begin{array}{c}\text { Value } \\
\text { (000 USD) }\end{array}$ \\
\hline $\begin{array}{l}\text { Milk and cream } \\
\text { (HS 40110) }\end{array}$ & 345.6 & 3,362 & 563.6 & 5,889 & 496.8 & 4,536 & 852.1 & 7,518 & 894.6 & 8,433 \\
\hline $\begin{array}{l}\text { Milk and cream } \\
\text { (HS 40120) }\end{array}$ & $1,856.3$ & 18,057 & 814.2 & 8,509 & 76.5 & 699 & 99.8 & 880 & 39.7 & 374 \\
\hline $\begin{array}{l}\text { Milk and cream } \\
\text { (HS 40130) }\end{array}$ & 323.4 & 3,145 & 161.3 & 1,686 & 724.1 & 6,611 & $1,077.6$ & 9,507 & $1,454.0$ & 13,707 \\
\hline $\begin{array}{l}\text { Milk and cream } \\
\text { (HS 40210) }\end{array}$ & $30,107.5$ & 292,855 & $22,806.7$ & 238,330 & $44,376.0$ & 405,153 & $50,120.9$ & 442,216 & $51,811.6$ & 488,428 \\
\hline $\begin{array}{l}\text { Milk and cream } \\
\text { (HS 40221) }\end{array}$ & 14.3 & 138,471 & 6.7 & 70,229 & 12.2 & 111,458 & 21.5 & 189,841 & 22.3 & 210,458 \\
\hline $\begin{array}{l}\text { Milk and cream } \\
\text { (HS 40229) }\end{array}$ & $20,930.0$ & 203,586 & $7,962.3$ & 83,206 & $11,133.0$ & 101,647 & $15,578.3$ & 137,447 & $12,719.7$ & 119,909 \\
\hline $\begin{array}{l}\text { Milk and cream } \\
\text { (HS 40291) }\end{array}$ & 199.7 & 1,943 & 13.3 & 139 & 13.6 & 124 & 6.9 & 60.5 & 2.2 & 21 \\
\hline $\begin{array}{l}\text { Milk and cream } \\
\text { (HS 40299) }\end{array}$ & 371.2 & 3,610 & 346.8 & 3,624 & 969.7 & 8,854 & $1,012.8$ & 8,936 & $1,226.6$ & 11,563 \\
\hline $\begin{array}{l}\text { Buttermilk } \\
\text { (HS 40390) }\end{array}$ & $2,528.7$ & 24,597 & $1,674.4$ & 17,498 & $3,411.6$ & 31,148 & $2,462.2$ & 21,724 & $2,052.6$ & 19,349 \\
\hline $\begin{array}{l}\text { Natural milk } \\
\text { constituents } \\
\text { (HS 40490) }\end{array}$ & 134.9 & 1,312 & 90.4 & 944 & 524.8 & 4,791 & 166.4 & 1,468 & 155.0 & 1,461 \\
\hline $\begin{array}{l}\text { Malt extract } \\
\text { (HS 190190) }\end{array}$ & $4,434.9$ & 43,138 & 3.310 .7 & 34,597 & 6,294 & 57,465 & $7,830.6$ & 69,089 & $9,287.2$ & 87,550 \\
\hline $\begin{array}{l}\text { Nonalcoholic } \\
\text { beverages } \\
\text { (HS 220290) }\end{array}$ & $5,432.9$ & 52,846 & $3,782.9$ & 39,532 & $4,782.8$ & 43,667 & $4,055.7$ & 35,783 & $3,629.6$ & 34,216 \\
\hline
\end{tabular}

Source: Kemenperin (2013); data has been analysed 
Table 6. The dynamic of farm gate fresh milk price, imported full cream milk powder and their price ratio, 1999-2013

\begin{tabular}{ccccccc}
\hline \hline Year & $\begin{array}{c}\text { Price FCMP } \\
(\mathrm{Rp} / \mathrm{kg})\end{array}$ & $\begin{array}{c}\text { Price FCMP }+ \\
5 \% \text { tax }(\mathrm{Rp} / \mathrm{kg})\end{array}$ & $\begin{array}{c}\text { Price FCMP }+5 \% \text { tax } \\
+ \text { transport cost } \\
(\mathrm{Rp} / \mathrm{kg})\end{array}$ & $\begin{array}{c}\text { Price equivalent } \\
\text { to fresh milk } \\
(\mathrm{Rp} / \mathrm{l})\end{array}$ & $\begin{array}{c}\text { Farm gate milk } \\
\text { price }(\mathrm{Rp} / \mathrm{l})\end{array}$ & $\begin{array}{c}\text { Ratio farm gate } \\
\text { milk price to import }\end{array}$ \\
\hline 1999 & 14,055 & 14,758 & 15,053 & 1,882 & 1,000 & 0.53 \\
2000 & 17,020 & 17,871 & 18,228 & 2,279 & 1,137 & 0.50 \\
2001 & 17,921 & 18,871 & 19,194 & 2,399 & 1,411 & 0.59 \\
2002 & 12,882 & 13,526 & 13,796 & 1,725 & 1,562 & 0.91 \\
2003 & 15,976 & 16,774 & 17,110 & 2,139 & 1,612 & 0.75 \\
2004 & 19,927 & 20,923 & 21,342 & 2,668 & 1,647 & 0.62 \\
2005 & 20,855 & 21,898 & 22,355 & 2,792 & 1,756 & 0.63 \\
2006 & 21,779 & 22,868 & 23,326 & 2,916 & 1,988 & 0.68 \\
2007 & 43,055 & 45,208 & 46,112 & 5,764 & 2,431 & 0.42 \\
2008 & 38,815 & 40,756 & 41,751 & 5,196 & 3,200 & 0.62 \\
2009 & 37,954 & 39,852 & 40,848 & 5,106 & 3,200 & 0.63 \\
2010 & 34,630 & 36,362 & 37,271 & 4,659 & 3,300 & 0.71 \\
2011 & 33,143 & 34,800 & 35,670 & 4,459 & 3,400 & 0.76 \\
2012 & 36,818 & 38,659 & 39,625 & 4,953 & 3,600 & 0.73 \\
2013 & 54,285 & 56,999 & 58,424 & 7,303 & 3,800 & 0.52 \\
\hline
\end{tabular}

FCMP: Full cream milk products

Source: Priyanti \& Saptati (2009) and further analyzed data

million business unit approximately $99 \%$ of total business; (2) Labor and work force opportunity for 101.7 million people (97,24\% workers); (3) Gross domestic product contribution of $57.1 \%$ (IDR 3.4 trillion); and (4) Investment value for IDR 927 trillion $(44.89 \%)$ in 2012 (Ministry of Small-Medium Enterprise and Cooperatives 2012).

One of the indicator for measuring competitiveness is domestic resource cost ratio (DRCR) approach, which recent study by Sirajuddin et al. (2013) indicated that dairy farming in Enrekang and Sinjay, South Sulawesi were incompetitive with the value of 1.297 and 2.059, respectively. A business with $0<$ DRCR $<1$ categorized as having good competitiveness, on the other hand, with DRCR $>1$ is economically inefficient or do not have any competitiveness. This is due to the higher domestic resource cost at its social price compared to that of additional output tradable value (Masters \& WinterNelson 1995). This implies that this business does not have any comparative advantage that considered as incompetitive business. Fortunately previous studies by Rachman (1998) had shown that dairy farming in Bogor and Bandung, West Java had various DRCR in a range of $0.63-0.86$. This could be due to better economies scale of dairy farming in West Java with more processing industry involved. This research has been done on three groups of credit scheme, i.e. small scale dairy farming ( $<4$ heads/farmer), recommended credit scheme of 7-10 and $>13$ heads/farmer in milk industry partnership approach. Furthermore, dairy farming in East Java has shown that farm gate price influenced by several components, i.e. milk price base, competitive incentives, loyalty, transport cost and feed incentives. These factors may build fresh milk price structure that has been bought by processing industry (Nugroho 2012). Feed and fuel price are indicators that may fluctuate dynamically and affected to overhead production cost at farmers' level.

In coping with the SME for processing milk industry, one of the milk businesses in Bogor, West Java, PT. Cisarua Mountain Dairy (Cimory Indonesia) implements the company strategy under their partnership through providing the highest farm gate prices to its dairy farmers. The strategy is being considered and provides a good benchmark and business model for the dairy industry to adopt. On the average, paid milk price is $10 \%$ higher using TPC and TS as the main criteria. To minimize bacteria contents during transportation fresh milk is delivered directly to the processing factory. This is an opportunity to increase the value along milk supply chain by linking the processing industry more closely to producers.

The company sells premium milk and dairy products such as fresh milk, yoghurt, pasteurized milk, UHT and cheese. These products require good quality 
of fresh milk from farmer's producer as a reward from getting attractive farm gate price. A price incentive is used to encourage better farm management practices as it is required by higher quality milk. It is reasonable that the industry provides technical services to the farmers as an instrument to achieve higher quality milk through direct participation and observation at all points of the process line. It took quite a long time for the farmers, however, to adapt to this mechanism at the very beginning, but now farmers get used to it as a standard daily management practices. Consequently, in 2006, they were capable of producing milk at 2.5 tons/day and in 2012; it became 15-20 tons/day involving 200 farmers and approximately 1,000 cows (Cimory Indonesia 2012).

Furthermore, the company has also launched a new processing factory in the District of Semarang, Central Java, in 2012 as a replication of a partnership model developed earlier in the District of Bogor, West Java. This could be due to good prospect of dairy business as shown by the previous factory, so that having a trend toward enlarging plant factory and increasing intensification in terms of output per factory on the entire system. The economic efficiency of dairy business is the main goal of the company, with one of the success factors is to build a mutual good partnership with farmers by implement good payment for good milk quality. Atzori et al. (2013) has reported that the main four components were very crucial to get contribution to profitability that associated with managerial and technical aspects, those are herd profile, milk quality and payment, good management and cow's reproduction rate. Reproduction would be the highest effect on economic importance of profitability, since this is true that it affected to milk production and in turn accounted for most of the economic benefits in programs with superior economic performance.

Strategy to group farmers into KUD has been ideally built independently on the basis of on-farm activities and the corporation management is proofing a success story by the SME milk processing which focuses at the marketing efficiency aspects. This strategy could be used extensively by similar companies through optimizing production partnership approach between SME and large milk processing. Moreover, contract of manufacturing which creates some benefits from guaranteed investment, production capacity, efficient promotion cost and marketing activities. The SME milk industry has to further be supported consistently by the government in order to achieve their goals gradually. The supports include: (1) Training and implementing food safety principles; (2) Applying method to produce good food; (3) Implementing food safety management based on HACCP principles; and (4) Certifying international quality assurance (ISO 9000, 22000, SQF). In addition, principles on good farming practices, good handling practices, good distribution practices, good retailing practices and good consumption practices need to be applied as the whole systems to present good quality food from farm to table. This needs to strengthen partnership cooperation between smallholders farmers and medium enterprises to produce fresh milk basis on a market driven by government program, such as school milk program.

In case of Indonesia, where most of the fresh milk product goes into processing factory, farm gate price would be the most important factor that can drive in achieving good milk production. There should be a mutually price benefit between the two parties, when there is a price incentive for farmers, dairy farming would be attractive to them and they may produce good quality milk. This will also need to have effective and integrated institutional marketing aspect from smallholder farmers as producers and medium scale of processing enterprise as consumers. Other than farm value cost is considered important that need to be discussed such as packaging, labeling, etc.

Integrated approach among institutions involved: cooperatives, livestock production and animal health services, bank and financial institution, private sectors that help farmers for some aspects: technical service, training, provision on information, etc. Cooperatives leaders need to build the cooperatives capacity to provide collective services required to attain high quality milk production-that is cooperatives are agents of change. Cooperative reform is then the first and highest priority to expand the dairy business, which they may need technical advice on how to gradually improve quality standards and what improvement measures to take. They need capacity building for extension workers who will disseminate information, training to farmers and monitor their practices as well as for the cooperatives staff working at milk collection centers.

\section{CONCLUDING REMARKS}

Indonesia has a potential opportunity to improve milk industry towards AEC market due to its 2 nd place of potential dairy population after Thailand. Domestic milk production needs to be increased beyond current capacity that indicates a strong challenge and high opportunity to improve domestic dairy production.

Building a partnership model between farmers and the SME milk processing plants, which are capable of paying higher farm gate prices to dairy farmers, should not become only 'a good concept on a paper' but it has to be an effort to 'put a theory into practice' since it is an opportunity to increase the milk value along the 
supply chain. Good marketing development and strategy will further prove that expansion of the SME milk industry partnership model could promote mutual equitable benefit.

In reference to all the above thought and practices, the Government of Indonesia is developing a comprehensive blueprint for the development of dairy industry and its follow up action plans to face the ASEAN economic community starting in 2015. All dairy stakeholders are expected to have their commitments to achieve the targets, among others. This will include: (1) application of good farm management practices; (2) provision of attractive farm gate prices to guarantee a feasible dairy farming; (3) building a partnership structure that mutually benefit between farmers and the SME; and (4) increasing the role of central and local government to support this industry.

\section{REFERENCES}

AEC. 2008. ASEAN economic community blueprint. ASEAN [Internet]. [cited 2013 Dec 18]. Available from: http://www.asean.org/communities/aseaneconomic-community/ite/annex-2-tariff-schedules

Atzori a S, Tedeschi LO, Cannas a. 2013. A multivariate and stochastic approach to identify key variables to rank dairy farms on profitability. J Dairy Sci. 96:33783387.

BPS. 2014. Perkembangan beberapa indikator utama sosialekonomi Indonesia. Jakarta (Indonesia): Badan Pusat Statistik.

Cimory Indonesia. 2012. Strategy to increase farmers' partnership to get better milk quality and attractive selling price. Roundtable discussion by Indonesian Center for Animal Research and Development. Bogor (Indonesia): ICARD.

Darmawan T. 2013. Marketing strategy and competitiveness of local milk production towards ASEAN economic community 2015. Development of partnership structure of small-medium enterprise milk industry towards ASEAN Economic Community 2015. Bogor (Indonesia): ICARD.

Devendra C, Leng RA. 2011. Feed resources for animals in Asia: Issues, strategies for use, intensification and integration for increased productivity. AsianAustralasian J Anim Sci. 24:303-321.

Devitt C, McKenzie K, More SJ, Heanue K, McCoy F. 2013. Opportunities and constraints to improving milk quality in Ireland: Enabling change through collective action. J Dairy Sci. 96:2661-2670.

DGLAHS. 2013. Livestock statistical book. Jakarta (Indonesia): Directorate General of Livestock Services and Animal Health Services.

GAIN. 2013. Dairy and products annual: Indonesian dairy annual 2013. Global Agricultural Information
Network [Internet]. [cited 2015 Jan 2]. Available from: http://www.fas.usda.gov/data/indonesia-dairyand-product-annual-2013

GKSI. 2013. Building farmer's partnership with milk processing industry. Paper presented in roundtable discussion: Development of partnership structure of small-medium enterprise milk industry towards ASEAN Economic Community 2015. Bogor (Indonesia): ICARD.

Kemenperin. 2013. Perkembangan impor komoditi hasil industri dari negara tertentu. Kementerian Perindustrian [Internet]. [disitasi 5 Juni 2014]. Tersedia dari: http://www.kemenperin.go.id/statistik/ query_komoditi.php?

Masters WA, Winter-Nelson A. 1995. Measuring the comparative advantage of agricultural activities: Domestic resource costs and the social cost-benefit ratio. Am J Agric Econ. 77:243-250.

Ministry of Small-Medium Enterprise and Cooperatives. 2012. Policy and action program of funding activities in the Ministry of Small-Medium Enterprise and Cooperatives. Roundtable discussion by Indonesian Center for Animal Research and Development. Bogor (Indonesia): ICARD.

Nugroho BA. 2012. The relevance of a rules-based fresh milk price structure policy in East Java: An evidence-based assessment. Int J Rural Stud. 19:1-7.

Oberman R, Dobbs R, Budiman A, Thompson F, Rossé M. 2012. The archipelago economy: Unleashing Indonesia's potential. McKinsey Global Institute [Internet]. [cited 2013 Dec 16]. Available from: http://www.mckinsey.com/insights/asia-pacific/the archipelago_economy

Priyanti A, Saptati RA. 2009. Impact of world's dairy price on farmer's level domestic milk price: The case of cattle farm cooperative in Bandung Utara, West JavaIndonesia. In: Proc Natl Semin Din Pembang Pertan dan Perdesaan. Bogor (Indonesia): ICASEP.

Rachman B. 1998. Keunggulan komparatif dan analisis sensitivitas usaha ternak sapi perah menurut pola pengusahaan di Jawa Barat. JITV. 3:1-7.

Sirajuddin SN, Siregar H, Amrawaty AA, Jusoff K, Nurlaelah S, Rohani S, Hastang A. 2013. Comparative advantage analysis on self dependent and business partnership of dairy farmers. Glob Vet. 10:165-170.

Tawaf R, Murti TW, Saptati RA. 2009. Kelembagaan dan tata niaga susu. Dalam: Santosa, Diwyanto, Toharmat, penyunting. Profil usaha peternakan sapi perah di Indonesia. Jakarta (Indonesia): LIPI Press. hlm. 301-346.

WEF. 2014. Insight report the global competitiveness index. World Econ Forum [Internet]. [cited 2013 Dec 23]. Available from: http://www.worldeconomicforum globalcompetitiveness_report_2014-2015 
Wolf CA. 2010. Understanding the milk-to-feed price ratio as a proxy for dairy farm profitability. J Dairy Sci. 93:4942-4948.
WTO. 2014. World tariff profiles. World Trade Organization [Internet]. [cited 2013 Dec 22]. Available from: http://www.wto.org/english/res_e/publications_e/worl d_tariff_profiles14_e_htm 